\begin{tabular}{|c|c|c|}
\hline BAWAL & $\begin{array}{c}\text { Tersedia online di: http://ejournal-balitbang.kkp.go.id/index.php/bawal } \\
\text { e-mail:bawal.puslitbangkan@gmail.com } \\
\text { BAWAL WIDYA RISET PERIKANAN TANGKAP } \\
\text { Volume 8 Nomor 1 April } 2016 \\
\text { p-ISSN: 1907-8226 } \\
\text { e-ISSN: 2502-6410 } \\
\text { Nomor Akreditasi: } 620 / A U 2 / P 2 M I-L I P I / 03 / 2015\end{array}$ & $\begin{array}{r}\text { BAWE } \\
\text { BAL }\end{array}$ \\
\hline
\end{tabular}

\title{
STRUKTUR KOMUNITAS IKAN DAN TINGKAT TROFIK DI WILAYAH GENANGAN WADUK JATIGEDE PRAINUNDASI, KABUPATEN SUMEDANG-JAWA BARAT
}

\author{
(FISH COMMUNITY STRUCTURE AND TROPHIC LEVEL AT JATIGEDE \\ RESERVOIRS AREA PRE INUNDATION, SUMEDANG DISTRIC WEST JAVA)
}

\author{
Andri Warsa ${ }^{* 1}$ Kadarwan Soewardi ${ }^{2}$, Sigid Hariyadi ${ }^{2}$ dan Joni Haryadi ${ }^{1}$ \\ ${ }^{1}$ Balai Penelitian Pemulihan dan Konservasi Sumber Daya Ikan, Jalan Jatiluhur PO BOX 01 Purwakarta, Jawa Barat-41152, \\ Indonesia \\ ${ }^{2}$ Fakultas Ilmu Kelautan dan Perikanan Institut Pertanian Bogor, Jalan Agatis, Dramaga, Bogor, Jawa Barat-Indonesia \\ Teregistrasi I tanggal: 18 Nopember 2015; Diterima setelah perbaikan tanggal: 28 Maret 2016; \\ Disetujui terbit tanggal: 01 April 2016
}

\begin{abstract}
ABSTRAK
Waduk Jatigede dibangun dengan membendung Sungai Cimanuk dan memiliki luas 4.122 ha serta merupakan waduk multifungsi. Tujuan penelitian ini adalah untuk mengetahui struktur komunitas ikan dan pemanfaatan sumber daya makanan oleh beberapa jenis ikan yang terdapat di DAS Cimanuk wilayah genangan Waduk Jatigede pra inundasi. Penelitian dilakukan setiap bulan pada Februari-Mei 2015 setiap bulan pada minggu pertama. Sampel ikan diperoleh dengan menggunakan jaring insang, jala, dan pancing. Percobaan penangkapan dilakukan di Sungai Cialing (inlet), Genteng, Cimanuk dan Cinambo (outlet). Ikan yang tertangkap dipisahkan berdasarkan jenisnya dan diukur panjang total serta ditimbang bobotnya. Untuk analisis kebiasaan makan kebiasaan makan, saluran pencernaan diambil dan diawetkan dengan formalin $4 \%$. Untuk identifikasi contoh ikan diawetkan dengan formalin $10 \%$. Ikan yang tertangkap selama penelitian sebanyak 11 jenis. Ikan yang dominan adalah lalawak dan genggehek. Rasio biomassa-kelimpahan ikan menujukkan bahwa komunitas ikan di Waduk Jatigede sebelum penggenangan dalam kondisi terganggu. Jenis makanan alami yang dimanfaatkan oleh komunitas ikan di Sungai Cimanuk wilayah genangan Waduk Jatigede adalah detritus, krustase, annelida, insekta, moluska, tumbuhan dan fitoplankton.
\end{abstract}

Kata Kunci: Jenis ikan; makanan alami; Sungai Cimanuk; Jatigede; prainudasi

\begin{abstract}
Jatigede Reservoir was build with damming of Cimanuk River has about 4.122 ha surface area as wel as multi purpose reservoir. The aim of the research is to known the fish community structure and trophic level by fishes community at Cimanuk River arround Jatigede Reservoir pre inudated. The research was carried out in February-May 2015. Fish sample was obtained by using gillnet, hook and cast net. The experimental fishings were setting at Cialing (inlet), Genteng, Cimanuk and Cinambo (outlet). Fish sample were separated according speciesand was measured of total lenght. To the analisys of food habits, digestive tract was preserved using formalin 4\%. For identification, fish sample was preserved using formalin 10\%. About 11 fish species were recorded. Dominan fish catches were Barbonymus balleroides and Mystacoleucus marginatus. According to Abundance-Biomass Comparisson, fish community was under pressure (unstable). Natural feeds observed were detritus, crustacea, annelida, insecta, molusca, plant and phytoplankton.
\end{abstract}

Keyword: Fish species; natural food; Cimanuk River; Jatigede; preinundation

Korespondensi penulis:

e-mail: andriwarsa@yahoo.co.id

Telp. (0264) 208768

Copyright @ 2016, BAWAL WIDYA RISET PERIKANAN TANGKAP (BAWAL) 


\section{PENDAHULUAN}

Waduk Jatigede memiliki luas \pm 4122 ha dan terletak di Kabupaten Sumedang, Jawa Barat. Waduk ini dibangun dengan membendung Sungai Cimanuk dan merupakan waduk multi fungsi. Fungsi Waduk ini antara lain sebagai pembangkit listrik, irigasi, pengendali banjir dan perikanan.

Komunitas ikan yang menghuni waduk pada awalnya merupakan ikan yang berasal dari perairan sungai yang dibendung (Kartamihardja, 2009). Evaluasi mengenai perubahan struktur komunitas ikan akan sangat membantu dalam menganalisis perubahan yang disebabkan oleh degradasi lingkungan(Champeau et al., 2009). Struktur komunitas ikan pada suatu ekosistem ditentukan oleh ketersediaan sumber daya makanan (Moreno \& Castro, 1995; Tjahjo \& Purnamaningtyas, 2008). Kompetisi dan predasi merupakan salah satu faktor yang mempengaruhi pola distibusi ikan baik secara temporal maupun spasial (Akin et al., 2005). Kebiasaan makan ikan berguna untuk mengetahui hubungan antara setiap jenis ikan dalam memanfaatkan sumber daya makanan alami yang tersedia (Kartamihardja 1994). Hal ini menjadi dasar pertimbangan penebaran dalam rangka peningkatan produksi tangkapan ikan (Tjahjo et al., 2006). Struktur komunitas ikan merupakan aspek dasar dalam pengelolaan sumber daya ikan (Estrada et al., 2008). Tujuan penelitian ini adalah untuk mengkaji struktur komunitas ikan dan pemanfaatan sumber daya makanan oleh beberapa jenis ikan yang terdapat di Waduk Jatigede sebelum penggenangan (prainundasi).

\section{BAHANDANMETODE Waktu dan Lokasi Penelitian}

Penelitian dilakukan pada Februari-April 2015 di wilayah Waduk Jatigede prainundasi dengan interval pengambilan sampel ikan setiap bulan pada minggu pertama. Sampel ikan diperoleh dari percobaan penangkapan menggunakan jaring ingsang (Gillnet), pancing (hook) dan jala (cast net). Pengambilan sampel dilakukan pada empat lokasi yaitu Sungai Cialing, Cimanuk, Genteng dan Cinambo (Gambar 1). Lokasi tersebut merupakan wilayah genangan Waduk Jatigede sehingga ikan yang ada di sungai tersebut akan mengisi perairan waduk. Sungai Cimanuk merupakan sungai utama sedangkan Cialing dan Cinambo merupakan anak sungai. Jaring insang dengan ukuran mata jaring 1-4 inci dengan interval 0,5 inci yang dipasang pada sore hari dan diangkat pada keesokan paginya. Untuk alat tangkap pancing digunakan untuk penangkapan sore hingga malam hari. Jala digunakan pada pagi hingga siang hari. Panjang total ikan diukur dengan papan ukur ketelitian $0,1 \mathrm{~cm}$ dan bobotnya ditimbang menggunakan timbangan digital ketelitian $0,1 \mathrm{mg}$. Pengukuran panjang total dan penimbangan bobot ikan dilakukan di lokasi penelitian. Sampel ikan yang diperoleh kemudian diawetkan dengan formalin $10 \%$ dan diidentifikasi dengan menggunakan buku identifikasi Kotellat et al. (1993).

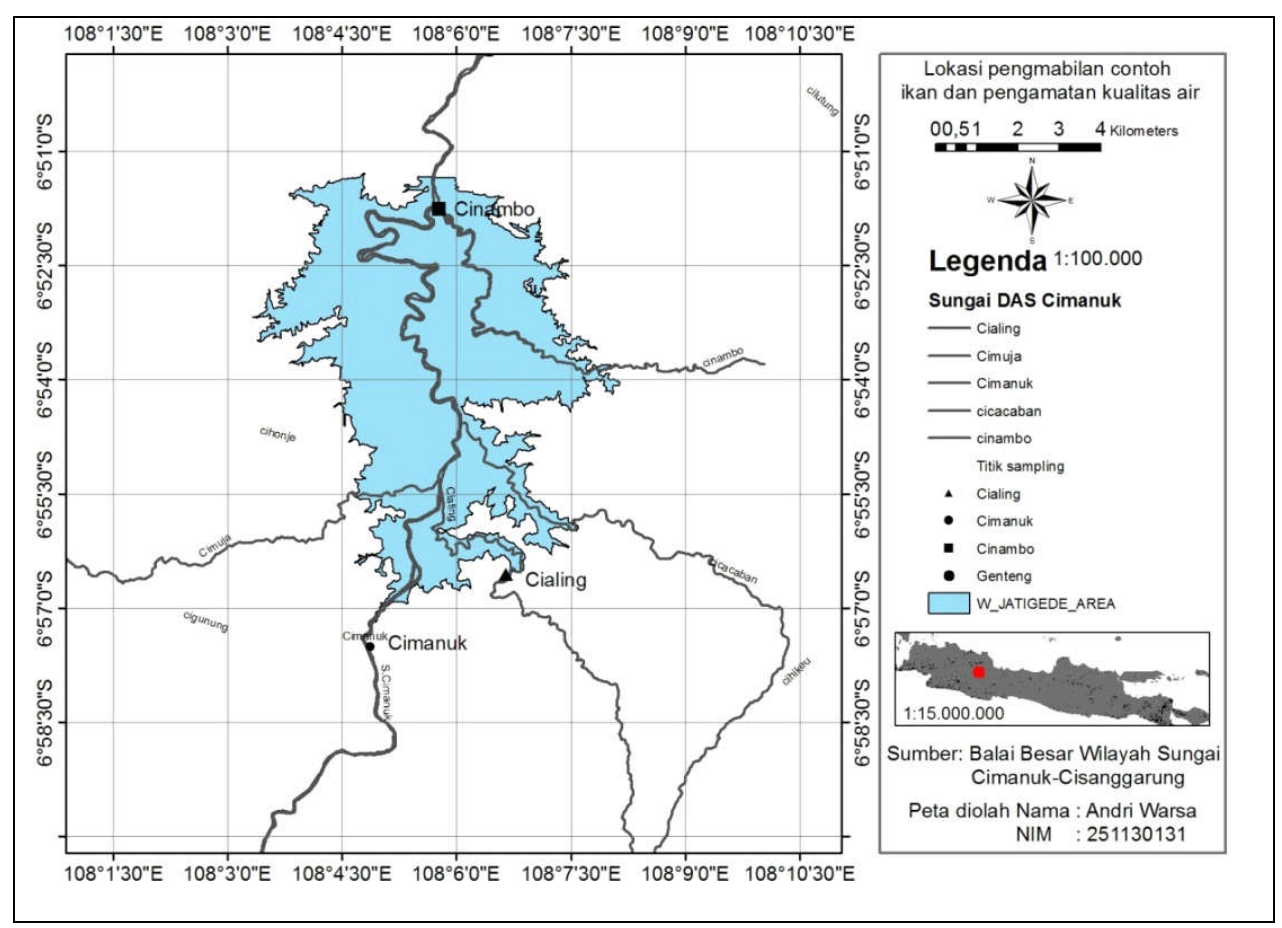

Gambar 1. Lokasi pengambilan sampel ikan dengan menggunakan berbagai alat tangkap percobaan.

Figure 1. Experimental fishing stations. 
Sampel ikan yang diperoleh kemudian dibedah, diambil saluran pencernaanya dan diawetkan dengan formalin $4 \%$. Untuk mengetahui jenis makanan yang dikonsumsi oleh ikan maka dilakukan pengamatan terhadap isis saluran pencernaan. Analisis contoh saluran pencernaan dilakukan di Laboratorium Biologi Balai Penelitian Pemulihan dan Konservasi Sumberdaya Ikan. Pengamatan organisme jenis makanan secara mikroskopis dan identifikasi memakai buku-buku dari Needham \& Needham (1963), Edmonson (1978) dan Sachlan (1982).

\section{Analisa Data}

Metode abundance-biomass comparison (ABC) digunakan untuk menganalisis kondisi struktur komunitas ikan (Clarke \& Warwick, 2001).

$$
\mathrm{W}=\sum \mathrm{S} \frac{(\mathrm{Bi}-\mathrm{Ai})}{1(50(\mathrm{~s}-1)}
$$

dimana:

$\mathrm{W}=$ indeks $\mathrm{ABC}(-1 \mathrm{s.d} 1)$

$\mathrm{Bi}=$ biomassa spesies ke $\mathrm{i}$

$\mathrm{Ai}=$ jumlah spesies ke $\mathrm{i}$

$\mathrm{S}=$ jumlah total spesies

Nilai relatif penting jenis ikan yang tertangkap dihitung dengan persamaan De Silva (2001).

$$
\begin{aligned}
& \% \mathrm{IRI}=100 *[(\% \mathrm{Wi}+\% \mathrm{Ni}) \% \mathrm{Fi}] /[\mathrm{S}((\% \mathrm{Wj}+\% \mathrm{Nj}) \% \\
& \mathrm{Fj})] \text {. }
\end{aligned}
$$

dimana:

IRI = nilai indeks relatif penting spesies ikan ke i $(\%)$

$\mathrm{W}=$ persentase bobot dari spesies ke i dalam total tangkapan (\%)

$\mathrm{N}$ = persentase jumlah dari spesies ke i dalam total tangkapan $(\%)$

$\mathrm{F}=$ frekwensi keberadaan spesies ke i dalam total tangkapan

Kebiasaan makanan ikan dianalisa menggunakan metode indeks bagian terbesar (index of preponderance) (Natarajan \& Jhingran, 1961) sebagai berikut:

$$
\mathrm{IP}=\frac{\mathrm{V}_{\mathrm{i}} \mathrm{xO}_{\mathrm{i}}}{\sum_{\mathrm{i}=1}^{\mathrm{n}}\left(\mathrm{V}_{\mathrm{i}} \mathrm{xO}_{\mathrm{i}}\right)} \times 100 \%
$$

dimana:

$\mathrm{IP}=$ indeks bagian terbesar (Index of Preponderance)

$\mathrm{V}$ = persentase volume makanan ikan jenis ke-i

$\mathrm{Oi}=$ persentase frekuensi kejadian makanan jenis ke-i

$\mathrm{n}=$ jumlah organisme makanan ikan $(\mathrm{i}=1,2,3, \ldots \mathrm{n})$

Estimasi tingkat trofik ikan dihitung dengan menggunakan persamaan yang dikemukan oleh Caddy \& Sharp (1986):
$\mathrm{T}_{\mathrm{t}}=1+\sum \frac{\mathrm{T}_{\mathrm{tp}} \mathrm{xI}_{\mathrm{p}}}{100}$

dimana:

$\mathrm{T}_{\mathrm{t}} \quad=$ tingkat trofik

$\mathrm{T}_{\mathrm{tp}}=$ tingkat trofik kelompok makanan ke-p

$\mathrm{I}_{\mathrm{p}} \quad=$ indeks preponderan kelompok makanan ke-p

\section{HASIL DAN BAHASAN \\ Hasil}

Jenis ikan yang tertangkap selama penelitian sebanyak 11 jenis antara lain ikan sapu-sapu (pterygoplichthys pardalis), sengal (Hemibragus nemurus), nilem (Osteochilus vittatus), nila (Oreochromis niloticus), gabus (Channa striata), lalawak (Barbonymus balleroides), hampal (Hampala macrolepidota), kekel (Glyptothorax platypogon), berod (Mystacembalus erythrotaenia), lele (Clarias batrachus), dan genggehek (Mystacoleucus marginatus).

Ikan yang tertangkap di lokasi penelitian pada umumnya berukuran kecil. ikan genggehek yang tertangkap berukuran panjang 8,0-11,5 cm. Ikan tersebut tertangkap pada gillnet dengan ukuran 1,0 dan 1,5 inci. Pada lokasi Sungai Cimanuk banyak tertangkap ikan lalawak dengan ukuran panjang total berkisar 9-18,8 cm yang tertangkap dengan gillnet. Ikan berod banyak tertangkap dengan alat tangkap pancing. Ikan sapu-sapu merupakan jenis ikan introduksi yang banyak tertangkap di lokasi Cialing. Ikan genggehek dan nila merupakan jenis yang tertangkap pada tiga lokasi penelitian yaitu Stasiun Cimanuk, Cialing dan Cinambo.

Ikan yang dominan berdasarkan jumlah dan bobot total adalah ikan genggehek (41 dan 12,7\%) dan lalawak (17,6 $\%$ dan 27,4\%) (Gambar 2). Hal yang sama juga diperoleh dengan analisa indeks relatif penting dengan nilai masing - masing 35,8 dan 22,5 \%. Hal ini menunjukkan bahwa, ikan genggehek dan lalawak merupakan ikan dominan berdasarkan bobot, jumlah individu maupun frekwensi tertangkapnya. Ikan berod yang tertangkap memiliki panjang berkisar $21,0-37,5 \mathrm{~cm}$ dan banyak tertangkap dengan alat tangkap pancing. Ikan hampal yang tertangkap jala mempunyai ukuran panjang total ikan berkisar antara 15,2-22,5 cm.

Hasil analisa menggunakan metode rasio biomassakelimpahan ikan menujukkan bahwa komunitas ikan di Waduk Jatigede prainundasi berada dalam keadaan tertekan dengan nilai indeks ABC yaitu -0,017. Hal tersebut terlihat dimana persentase kumulatif jumlah individu berada diatas biomassa ikan yang mengindikasikan ikan di lokasi tersebut mempunyai ukuran yang kecil. 
Jenis makanan alami yang dimanfaatkan oleh komunitas ikan di Waduk Jatigede prainundasi antara lain detritus, krustase, cacing, insekta, moluska, tumbuhan dan fitoplankton. Makanan alami yang merupakan makanan utama antara lain tumbuhan, insekta dan anelida (Tabel 1).

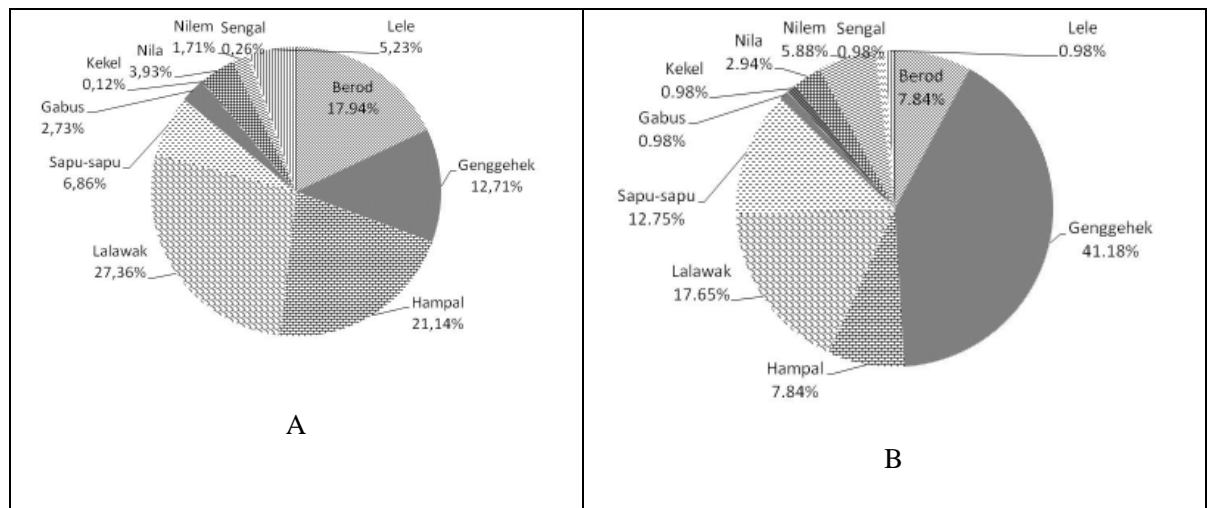

Gambar 2. Persentase hasil tangkapan dengan alat tangkap percobaan di Waduk Jatigede berdasarkan A. Bobot dan B Jumlah individu.

Figure 2. Percent of catch using experimental fishing in Jatigede Reservoir based on A. Weight and B. Number of individu.

Tabel 1. Kebiasaan makanan beberapa jenis ikan di Waduk Jatigede pra inundasi

Table 1. Food habits of some fishes in Jatigede Reservoir pra inundation

\begin{tabular}{|c|c|c|c|c|c|c|c|c|}
\hline \multirow{2}{*}{$\begin{array}{c}\text { Jenis ikan/ Fish } \\
\text { species }\end{array}$} & \multicolumn{7}{|c|}{ Kelompok makanan/Food group (\%) } & \multirow[t]{2}{*}{$\begin{array}{c}\text { Tingkat trofik/ } \\
\text { Trophic level }\end{array}$} \\
\hline & Fito & Tumbh & Detri & Annelida & Molusk & Krust & Inskt & \\
\hline Sapu-sapu & 1,68 & 0,74 & 97,58 & & & & & 2,00 \\
\hline Sengal & & 75 & & & & & 25 & 2,38 \\
\hline Nilem & & 78,79 & & & & & 21,21 & 2,21 \\
\hline Nila & 18,81 & 81,18 & 0,02 & & & & & 2,00 \\
\hline Gabus & & & & & & & 100 & 4,00 \\
\hline Lalawak & & 94,17 & & & 2,6 & & 3,24 & 2,07 \\
\hline Hampal & & & & & & 100 & & 3,00 \\
\hline Kekel & & & & 100 & & & & 3,00 \\
\hline Berod & & 19,19 & 5,81 & 4,65 & & 13,96 & 56,39 & 3,00 \\
\hline Lele & & & & 69,23 & & & 30,77 & 3,15 \\
\hline Genggehek & 2,44 & 93,27 & & 0,17 & & 0,02 & 4,10 & 2,06 \\
\hline \multirow[t]{2}{*}{ Keterangan/remark: } & $\begin{array}{l}\text { Anelida ( } \\
\text { Inskt: ins }\end{array}$ & $\begin{array}{l}\text { orm), Detri: } \\
\text { kta (Insecta }\end{array}$ & $\begin{array}{l}\text { tritus ( } \\
\text { Molusk: }\end{array}$ & $\begin{array}{l}\text { itus), Fito: I } \\
\text { luska (Molt }\end{array}$ & $\begin{array}{l}\text { pplankton (I } \\
\text { a), Krust: } 1\end{array}$ & $\begin{array}{l}\text { hytoplan } \\
\text { rustase (c }\end{array}$ & $\begin{array}{l}\text { ton), Tum } \\
\text { ustacea) }\end{array}$ & h: Tumbuhan (Plant), \\
\hline & 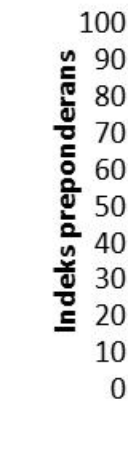 & b. ब9 & & & $\frac{1}{2}$ & $\begin{array}{l}\square \text { Detrit } \\
\square \text { Crusta } \\
\text { Anneli } \\
\text { m Insect } \\
\text { 四 Molus } \\
\mathbb{Q} \text { Tumb } \\
\text { 橉Fitopl }\end{array}$ & $\begin{array}{l}\text { s } \\
\text { ea } \\
\text { la } \\
\text { a } \\
\text { han } \\
\text { aton }\end{array}$ & \\
\hline
\end{tabular}

Gambar 3. Komposisi kelompok makanan pada beberapa jenis ikan di Waduk Jatigede pra inundasi.

Figure 3. Food composition of some fishes in Jatigede Reservoir prainundation. 
Hasil analisis kebiasaan makanan (Tabel 1 dan Gambar 3) menunjukkan bahwa ikan sapu-sapu, sengal, nilem, nila, lalawak dan genggehek berperan sebagai ikan herbivora dengan nilai tingkat trofik $<2,5$. Ikan sapu-sapu memanfaatkan detritus sebagai makanan utamanya sedangkan ikan sengal, nilem nila, lalawak dan genggehek memanfaatkan tumbuhan sebagai makanan utamanya. Kelompok ikan ominivora cenderung karnivora (nilai tingkat trofik adalah 3,00) terdiri dari hampal, kekel dan berod. Ikan hampal memanfaatkan krustase, ikan kekel memanfaatkan anelida sedangkan ikan berod memanfaatkan insekta sebagai makanan utamanya. Ikan lele dan gabus berperan sebagai ikan karnivora dengan nilai tingkat trofik masing-masing adalah 3,15 dan 4,00. Kedua jenis ikan tersebut masing-masing memanfaatkan cacing dan insekta sebagai makanan alaminya.

\section{Bahasan}

Jenis ikan yang tertangkap di Sungai Cimanuk selama penelitian banyak tertangkap di beberapa Sungai di Indonesia. Jenis ikan gabus merupakan jenis ikan yang juga banyak ditemukan di Sungai Maro, Merauke (Astuti et al., 2008). Hampal juga tertangkap di Sungai Suak Putat, Jambi (Nurdawati, 2010). Ikan berod banyak tertangkap di Sungai Musi bagian hilir (Ali \& Rais, 2010). Ikan hampal dan genggehek merupakan jenis ikan yang tertangkap cukup banyak di kawasan Pegunungan Muller, Kalimantan Tengah dengan persentase sebesar 5,52 dan 6,21\% (Haryono, 2004). Ikan sapu-sapu yang tertangkap di Sungai Cimanuk mempunyai potensi untuk menjadi pesaing bagi ikan-ikan asli (Sjafei et al., 2001). Ikan nilem dan lalawak merupakan jenis ikan yang banyak tertangkap di perairan sekitar Taman Nasional Bogani Nani Wartabone, Sulawesi Utara dengan persentase 4,4 dan 15,2\% (Haryono et al., 2003).

Ikan yang mengisi waduk yang dibangun dengan membendung suatu sungai umumnya berasal dari sungai tersebut. Ikan mampu beradaptasi dengan perubahan lingkungan akan menjadi dominan (Kartamihardja, 2008). Ikan genggehek, lalawak dan hampal kemungkinan menjadi dominan, dimana hal tersebut juga terjadi di Waduk Jatiluhur (Purnamaningtyas, 1994). Ikan yang tetap ada setelah pembendungan Sungai Citarum antara lain hampal, lalawak, nila, dan sapu-sapu (Hendianto \& Purnamaningtyas, 2011). Hal ini disebabkan oleh karena ikan tersebut mampu beradaptasi dengan perubahan habitat dari mengalir menjadi tergenang (Tjahjo \& Umar, 1994). Untuk jenis ikan tawes dan genggehek sudah tidak tertangkap lagi (Kartamihardja 2008).

Bobot suatu jenis ikan dapat digunakan sebagai suatu dasar penilaian kondisi lingkungan dimana kedua hal tersebut dipengaruhi oleh ketersediaan makanan (Felix et $a l ., 2008)$. Indeks ABC di Waduk Jatigede prainundasi ini lebih rendah jika dibandingkan dengan nilai indeks ABC di beberapa badan air di Afrika (Yemane et al., 2005) dan lebih tinggi jika dibandingkan di Situ Panjalu (-0,228) (Warsa \& Purnomo, 2012). Lokasi penelitian di wilayah genangan Waduk Jatigede merupakan lokasi yang dekat dengan pemukiman dan lahan pertanian. Tata guna lahan DTA yang berupa lahan pertanian dan pemukiman. Hal ini memungkinkan masuknya bahan pencemaran berupa nutrien, pestisida dan erosi tanah pertanian (Agustiningsih et al., 2012). Hal ini menyebabkan terjadinya peningkatan kesuburan perairan (Payasiri, 2000). Komunitas ikan dipengaruhi oleh kondisi lingkungan misalnya kecerahan dan kedalaman serta interaksi dengan faktor biotik lainnya (Suarez et al., 2001). Kecerahan di Sungai Cimanuk berkisar 24-31,5 cm (Tresna et al., 2012).

Persaingan pemanfaatan sumber daya makanan oleh ikan yang ada pada suatu ekosistem akan berdampak pada keanekaragaman ikan yang ada pada ekosistem tersebut (Mason et al., 2008). Ikan gabus bersifat predator dimana pada fase dewasa ikan ini banyak memanfaatkan udang, serangga, katak, udang dan ikan (Muflikhah, 2007). Ikan gabus di Rawa Taliwang memanfaatkan ikan sebagai makanan utamanya dan bersifat sebagai predator (Tjahjo \& Purnomo, 1998). Makanan alami ikan nilem di sungai wilayah genangan Waduk Jatigede hampir sama dengan ikan nilem di Waduk Penjalin yaitu memanfaatkan tumbuhan (Hedianto et al., 2013). Makanan utama ikan hampal yang tertangkap selama penelitian berbeda dengan pakan alami ikan hampal di Waduk Jatiluhur. Ikan hampa yang tertangkap di Waduk Jatiluhur memanfaatkan ikan sebagai makanan utamnya (Tjahjo et al, 2009). Terdapat perbedaan pemanfaatan makanan alami oleh ikan di Sungai Cimanuk Bagian Hulu dan Sungai Cimanuk wilayah genangan Waduk Jatigede prainundasi. Hasil Penelitian (Tresna et al., 2012). Di Sungai Cimanuk Bagian hulu, Ikan nilem, genggehek sapu-sapu, sengal dan nila memanfaatkan fitoplankton sebagai makanan utama dengan nilai indeks bagian terbesar masing-masing adalah 79,$0 ; 62,8 ; 56,4 ; 62,3$ dan 54,1. Tingkat trofik komunitas ikan di Sungai Cimanuk bagian hulu berkisar antara 2,06-2,94.

Ikan Sungai Cimanuk yang kemungkinan menghuni perairan Waduk Jatigede kemungkinan akan mengalami perubahan dalam memanfaatkan makanan alami. Pada saat penggenangan ikan nila (Purnomo \& Satria, 2003; Purnomo et al., 2013) dan genggehek (Kartamihardja, 1994) memanfaatkan fitoplankton sebagai makanan utamanya. Ikan sengal (Tjahjo \& Umar, 1994), hampal (Herawati, 2013) dan gabus (Tjahjo, 1988) memanfaatkan ikan sebagai pakan alaminya.

\section{KESIMPULAN}

Di DAS Cimanuk wilayah genangan Waduk Jatigede ditemukan sekitar 11 jenis ikan. Ikan yang dominan adalah 
genggehek dan lalawak. Komunitas ikan di DAS Cimanuk wilayah genangan Waduk Jatigede berada pada kondisi tertekan. Ikan sengal, nila, lalawak, genggehek dan nilem mempunyai peluang kompetisi yang besar karena memanfaatkan tumbuhan sebagai makanan utamanya.

\section{PERSANTUAN}

Tulisan ini adalah bagian dari Tesis dengan judul" Model perencanaan pengelolaan dan optimalisasi waduk berbasis perikanan budidaya dan perikanan alami (Studi kasus: Waduk Jatigede, Sumedang-Jawa Barat)" tahun 2015.

\section{DAFTAR PUSTAKA}

Agustiningsih, D. Sasongko, S. B \& Sudarno. (2012). Analisa kualitas air dan beban pencemaran berdasarkan penggunaan lahan di sekitar Sungai Blukar Kabupaten Kendal. Prosiding Seminar Nasional Pengelolaan Sumberdaya Alam dan Lingkungan. (p. 30-37).

Akin, S., Buhan, E., Winemiller, K. O \& Yilmaz, H. (2005). Fish assemblage structure of Koycegiz Lagoon estuary, Turkey: Spatial and temporal distibution patterns in relation to environmental variation. Estruarine, Coastal and Shelf Science (64), 671 - 684.

Ali, M \& Rais, A. H. (2010). Habitat ikan tilan (Mastacembalus erythrotaenia) di perairan Sungai Musi Bagian Hilir. Seminar Nasional Tahunan VII Hasil Penelitian Perikanan dan Kelautan (p. 1-5). Eds: Djumanto, H. Saksono., N. Probosunu., R. Widaningrum \& Suad.

Caddy, J. F \& Sharp, G. D. (1986). An ecological framework for marine fishery investigation. FAO. Fish. Tech. Pap 283: p. 152.

Champeau, T. R., Stevens, P. W \& Blewett, D. A. (2009). Comparison of fish community metrics to assess long term changes and hurricane impact at Peace River, Florida. Florida Scient. 72 (4), 289-309.

Clarke, K. R \& Warwick, R.M. (2001): Change in marine communities: An approach to statistical analysis and interpretation, $2^{\text {nd }}$ Edn. PRIMERE: Plymouth. Natural Environment Research Council, UK.

Colwell, R. K \& Futuyma, D. J. (1971). On the measurement of niche breadth and overlap. Ecology. 54(4), 567 576.

De Silva, S. S. (2001). Reservoir and culture-based fisheries: biology and management. Proceedings of an International Workshop held in Bangkok,
Thailand from 15-18 February 2000. ACIAR Proceedings No. 98. pp. 384.

Edmonson, W.T. (1959). Freshwater biology. 2 nd Ed (p.1248). John Wiley \& Sonc. Inc. New York.

Estrada, J. C. G., Vasconcelos, R \& Costa, M. J. (2008). Estimating fish comunity diversity from environmental features in the Tagus Estuary (Portugal): Multiple Regression and Artificial Neural Network approach. $J$. Appl. Ichthyol. 24, 150-162.

Felix, K.K., Dramane, D., Mamadou, O., Allasane, O \& Germain, G. (2008). Use of the lenght in determination of indices of diversity and equitability of ichtyofauna. European Journal of Scientific Research. 23(3), 458464.

Haryono. (2004). Komunitas ikan suku Cyprinidae di perairan sekitar Butik Batikap kawasan Pegunungan Muller Kalimantan Tengah. Jurnal Iktiologi Indonesia. 4(2), 79-85.

Haryono, A., Tjakrawidjaja, H \& Riyanto, A. (2003). Iktiofauna di Perairan Sekitar Gunung Kabela Taman Nasional Bagani Nani Wartabone Sulawesi Utara. Jurnal Iktiologi Indonesia. 2(2), 31-40.

Hedianto, D.A \& Purnamaningtyas, S. E. (2011). Penerapan kurva ABC (Rasio kelimpahan/biomassa) untuk mengevaluasi dampak introduksi terhadap komunitas ikan di Waduk Ir. H. Djuanda. Dalam Kartamihardja ES. Rahardjo MF \& Purnomo K. Prosiding Nasional Pemacuan Sumberdaya Ikan III (p.1-11).

Hedianto, D. A., Purnomo, K \& Warsa, A. (2013). Interaksi pemanfaatan pakan alami oleh komunitas ikan di Waduk Penjalin, Jawa Tengah. Bawal. 5(1), 33-40.

Herawati, T. H., Handa., Purnamaningtyas, S. E. (2013). Peluang keberhasilan restocking beberapa jenis ikan di Waduk Jatiluhur berdasarkan kebiasaan dan luas relung makanannya. Kartamihardja ES, Rahardjo MF, Krismono, Suhora A, Purnomo K. Prosiding Nasional Pemulihan dan Konservasi Sumberdaya Ikan IV: KSP PI32.

Kartamihardja, E. S. (1994). Pembagian sumberdaya pakan diantara lima jenis ikan yang dominan di Waduk Kedungombo, Jawa Tengah. Bul. Penel. Perik. Darat. 12(2), 133-140.

Kartamihardja, E. S. (2008). Perubahan komposisi komunitas ikan dan faktor-faktor penting yang mempengauhi selama empat puluhtahun umur Waduk Djuanda. Jurnal iktiologi Indonesia 8(2), 67-78. 
Kartamiharja, E. S. (2009). Mengapa ikan bandeng diintroduksi di Waduk Djuanda, Jawa Barat. Prosiding. Forum Pemacuan Sumber daya Ikan II. PI-06. p. 14.

Kottelat, M., Witten, A., Kartikasari, S. N \& Wirjoatmodjo, S. (1993). Freshwater fishes of Western Indonesia and Sulawesi (p. 377). Periplus, Hongkong.

Mason, N. W. H., Lanoiselee, P. Irz. C., Mouillot, D \& Argillier, C. (2008). Evidence thet niche specialization explains species energy relationships in lake fish communities. Journal of Animal Ecology. (77), 285296.

Moreno, T \& Castro, J. J. (1995). Community structure of the juvenile of coastal pleagic fish species in the Canary Isand waters. Sci. Mar 59 (3), 405 - 413.

Moyle, P.B \& Senanayake, F.R. (1984). Resources partitioning among fishes of rain forest streams in Sri Lanka. J. Zool. London. 202, 195-223.

Muflikhah, N. (2007). Domestikasi ikan gabus (Channa striata). Bawal. 1 (5), 169-175.

Natarajan, A.V \& Jhingran, A. G. (1961). Index of prponderance- a method of grading the food elements in the stomach analysis of fishes. Indian Journal of fisheries. 8(1), 54-59.

Needham, J.G \& Needham, P.R. (1963). A guide to the study of freshwater biology. Fifth Edition (p.180). Revised and Enlarged. Holden Day. Inc. San Fransisco.

Nurdawati, S. (2010). Keanekaragaman jenis ikan dan komposisi hasil tangkapan ikan dengan alat tangkap jermal di Sungai Suak Putat, Jambi. Seminar Nasional Tahunan VII Hasil Penelitian Perikanan dan Kelautan. Eds: Djumanto, H. Saksono., N. Probosunu., R. Widaningrum \& Suad: 1-5.

Payasiri, S. (2000). Eutrophication and algae bloom problem in Kotmale Reservoirs, Sri Lanka. Edts: Timotius KH \& Goltenboth. Tropical Limnology Vol II. Satrya Wacana University Press. Salatiga. Indonesia.

Purnomo, K \& Satria, F. (2013). Beberapa aspek biologi ikan nila (Oreochromis niloticus) di Waduk Malahayu. Kartamihardja ES, Rahardjo MF, Krismono, Suhora A, Purnomo K. Prosiding Nasional Pemulihan dan Konservasi Sumberdaya Ikan IV: KSP PI 32.

Purnomo, K., Warsa, A \& Kartamihardja, E. S. (2013). Daya dukung dan potensi produksi ikan Waduk Sempor di
Kabupaten Kebumen-Propinsi Jawa Tengah. J. Lit. Perikan. Ind 19(4), 203-212.

Purnamaningtyas, S. E. (1994). Pengaruh pembendungan Sungai Citarum terhadap struktur komunitas ikan di Waduk Jatiluhur Jawa Barat. Bul. Penel.Perik. Darat. 12(2), 41-53.

Pianka, E. R. (1971). Niche overlap and Diffuse competition. Proc. Nat. Acad. Sci. 71(5), 2141 - 2145.

Sjafei, D. S., Wirjoatmodjo, S., Rahardjo, M. F \& Susilo, S. B. (2001). Fauna ikan di Sungai Cimanuk, Jawa Barat. Jurnal Iktiologi Indonesia. 1(1), 1-6.

Sachlan, M. (1982). Planktonologi (p.156.) Fakultas Peternakan dan Perikanan Universitas Diponegoro Semarang.

Suarez, Y. R., Petrere, Jr. M \& Catella, A. C. (2001). Factor determining the structure of fish communities in Pantanal Lagoons (MS, Brazil). Fisheries Management and Ecology. (8), 173-186.

Tjahjo, D.W.H. (1988). Kebiasaan makan komunitas ikan di Waduk Saguling Jawa Barat. Bull. Penel. Perik. Darat. 7(1), 86-91.

Tjahjo, D.W.H \& Umar, C. (1994). Interaksi beberapa jenis ikan di Waduk Jatiluhur, Jawa Barat. Bull. Perik. Darat. 12(2), 67-77.

Tjahjo, D. W. H \& Purnomo, K. (1998). Studi interaksi pemanfaatan pakan alami antara ikan sepat (Trichogaster pectoralis), betok (Anabas testudineus), mujair (Oreochromis mossambicus), nila (O. niloticus) dan gabus (Channa striatus) di Rawa Taliwang. J.Lit.Perik.Ind. 4(3), 50 - 59.

Tjahjo, D. W. H., Kartamihardja, E. S \& Purnamaningtyas, S. E. (2006). Kualitas air, produktivitas primer, dan potensi produksi ikan Waduk Darma untuk mendukung kehidupan dan pertumbuhan udang galah (Macrobrchium rosenbergii) yang diintroduksikan. J.Lit.Perikan.Ind. 12(1), 1-12.

Tjahjo, D. W. H \& Purnamaningtyas, S. E. (2008). Kajian kebiasaan makanan, luas relung, dan interaksi antar jenis ikan di Waduk Cirata, Jawa Barat. Jurnal Iktiologi Indonesia. 8(2), 59-65.

Tjahjo, D. W. H., Purnamaningtyas, S. E \& Suryandari, A. (2009). Evaluasi peran jenis ikan dalam pemanfaatan sumberdaya pakan dan ruang di Waduk Ir. H. Djuanda, Jawa Barat. J.Lit.Perikan.Ind.15(4), 267-276. 
Warsa, A., et al / BAWAL Vol. 8 (1) April 2016: 29-36

Tresna, L. K., Dhahiyat, Y \& Herawati, T. (2012). Kebiasaan makanan dan luas relung ikan di hulu Sungai Cimanuk Kabupaten Garut, Jawa Barat. Jurnal Perikanan dan Kelautan. 3(3), 163-173.

Warsa, A \& Purnomo, K. (2012). Struktur komunitas ikan pasca penebaran ikan patin (Pangasianodon
Hypopthalmus) di Situ Panjalu, Kabupaten CiamisJawa Barat. J. Lit. Perikan. Ind. 18(3), 145-156.

Yemane, D., Field, J. G \& Leslie,R. W. (2005). Exploring the effect of fishing on fish assemblages using abundance biomass comparison (ABC) curves. ICES Journal of Marine Science. 62, 374-379. 